\title{
Antimicrobial resistance of Escherichia coli in wild animals ${ }^{1 \star}$
}

\author{
Maja Velhner', Ljiljana Suvajdžić ${ }^{2}$, Jelena Petrović ${ }^{1}$, Marcela Šeperanda ${ }^{3}$ \\ ${ }^{1}$ Scientific Veterinary Institute "Novi Sad”, Novi Sad, Serbia \\ ${ }^{2}$ Faculty of Medicine, Department of Pharmacy, Novi Sad, Serbia \\ ${ }^{3}$ University of Osijek, Faculty of Agriculture Osijek, Croatia
}

\begin{abstract}
The paper presents the recent finding of resistance phenotype and distribution of resistant genes in Escherichia Coli (E. coli) isolated from wild life. The resistance distribution was depended on animal species, their natural habitat, and some seasonal variations were also evident. Wild animals residing close to the farms were more often spreaders of resistant bacteria than those found in nature. It was shown that humans have an important role in appearance and dissemination of resistant E. coli in population of wild animals.
\end{abstract}

Key words: wild animals, E. coli, resistance, resistant genes, antibiotics

\footnotetext{
$1^{*}$ This work is supported by a grant from the Ministry of Education, Science and Technological Development, Republic of Serbia, Project number TR 31084.

E-mail: maja@niv.ns.ac.rs
} 


\title{
ANTIMIKROBNA REZISTENCIJA ESCHERICHIA COLI KOD DIVLJIH ŽIVOTINJA
}

\author{
Maja Velhner ${ }^{1}$, Ljiljana Suvajdžić ${ }^{2}$, Jelena Petrović ${ }^{1}$, Marcela Šeperanda ${ }^{3}$ \\ ${ }^{1}$ Naučni institute za veterinarstvo "Novi Sad", Novi Sad, Srbija \\ ${ }^{2}$ Medicinski fakultet, Departman za farmaciju, Novi Sad, Srbija \\ ${ }^{3}$ Univerzitet u Osijeku, Poljoprivredni fakultet, Osijek, Hrvatska
}

\section{Kratak sadržaj}

U radu su opisana najnovija saznanja o distribuciji rezistentnih sojeva E. coli i gena koji kodiraju rezistenciju za E. coli izolovanih kod divljih životinja. Distribucija rezistencije zavisi od vrste životinja, prirode njihovih staništa, a kod nastanka rezistencije, uočavaju se i sezonske varijacije. Rezistentni sojevi $E$. coli češće su ustanovljeni kod divljih životinja nastanjenih u blizini farmi, u odnosu na vrste slobodne u priodi. Dokazana je uloga čoveka u pojavi i širenju rezistencije $E$. coli u populaciji divljih životinja.

Ključne reči: divlje životinje, E. coli, rezistancija, rezistantni geni, antibiotici

\section{Introduction}

Mutations on genes conferring antimicrobial resistance (AMR) in E. coli, from wild animals are rare, since treatment with antimicrobials during their life time is not possible. However, if contact with the resistant bacteria happens in nature, the dissemination of resistant genes in wild life becomes evident. Wild animals that live close to the livestock may harbor resistant bacteria and contaminate the surroundings. Migrating birds can transmit resistant genes from a long distance contaminating the environment as well (Allen et al., 2011). Water flows near the farms can be polluted, providing opportunity for different pathogens to come in contact with the wild animals. Sometimes environmental contamination happens even if farms are situated far from the woods and meadows implicating the role of agricultural business in dissemination of resistant genes. Since there are various means by which resistant genes become reservoirs in nature, it is important to monitor its presence applying seasonal monitoring or surveys. The sampling strategy thus becomes crucial and needs to be done with care considering the nature of the habitat. The most frequent sample is feces that need to be collected by swabbing. From wild birds the feces can be collected as a cloacal swab or from feces found in places where the wild birds reside. The samples need to be collected in sterile tubes and then sent to 
laboratory as soon as possible. For the isolation and identification of E. coli, a highly selective media is used and characteristic colonies are further identified, applying biochemical parameters (Suvajdžić et al., 2012). The AMR phenotype is determined according to the recommendation of the CLSI (The Clinical and Laboratory Standards Institute). It is often difficult to find a connection between the type of AMR and its source and this is why much effort is needed toward the research of the true nature of resistances in wild life. However, anthropogenic and natural AMR of bacteria in wild animals is suggestive and can be more frequent than previously thought. The goal of this paper is to present recent findings in terms of resistance of $E$. coli isolated from wild animal species and to outline resistance genes found in animals from various habitats.

\section{Wild bird species could spread resistant bacteria}

The first report of extended-spectrum $\beta$-lactamase, (ESBL) producing $E$. coli from wild animals came from Portugal. The ESBL phenotype in E. coli was discovered during an AMR survey in wild animals residing in natural parks in the north and central areas of the country. An extended-spectrum $\beta$-lactamase producing $E$. coli was found in fecal samples in one owl, otherwise susceptible to non- $\beta$-lactam antibiotics. The $E$. coli was carrying $b l a_{\text {TEM } .52}$ genes. The $E$ coli isolated from one bird of prey were $b l a_{\text {СТХ-M-14 }}$ and bla TЕM -52 $_{20}$ positive and this isolates were also resistant to nalidixic acid (NAL) and tetracycline (TET). In two other birds of prey the $b l a_{C[\mathrm{CM}-14}$ and $b l a_{\text {ГЕM }-1}$ gene was found in otherwise multiple resistant $E$. coli while in another bird of prey (the fourth isolate) $E$. coli was carrying different $b l a_{\text {СЕМ }}$ genes. The $E$. coli which had the $b l a_{\mathrm{SHV}-12}$ gene was also found in one bird of prey (Costa et al., 2006). Further investigation on the AMR to the wide spectrum of antibiotics in E. coli from 24 different wild animals residing in Natural Parks in Portugal reveals different resistance patterns. In the two birds of prey, the E. coli was resistant to ampicillin and cefotaxime. The blaTEM ${ }_{52}$ gene was found in one isolate, while the second isolate possessed the bla'TEM ${ }_{-1}$ gene. Both of these two isolates also posses the bla $a_{\text {CTX.M-14 }}$ type gene. In the five isolates resistant to gentamicin, the genes encoding aminoglycoside acetyltransferase the aac(3)-II or aac(3)-IV were found. Gene's aadA1 or aadA2 encoding aminoglycoside adenylyltransferase modifying streptomycin was present in 22/25 streptomycin resistant isolates. Efflux mediated tetracycline resistant genes tet $A$ and/or tet $B$ was detected in 39 isolates from this collection. It was postulated that the reservoir of resistant genes transferable to animals and humans is attributed to some comensal bacteria that are present in the intestine of wild animals (Costa et al., 2008). Wild geese residing in agricultural areas were showing resistance phenotype 
much more frequently than birds from the wildness. In the research of Cole et al. (2005), a higher incidence of antimicrobial resistance was connected to the interaction of birds with the waste lagoons in Craven County. In fact, the resistance to antimicrobials was as common as in pigs raised in relatively close proximity. Wild geese residing in Georgia with no contact to swine farms or waste waters displayed only resistance to cefoxitin-amoxicillin/clavulanic acid-cephalotin in 19\% isolates. Another research showed that 2 out of $396 E$. coli from wild geese residing in wildlife in Belgium were resistant to ceftiofur and yet they carried extended-spectrum $\beta$-lactamase genes. The screening was directed to genes encoding: TEM, SHV, CTX-M- and CMY enzymes. One isolate has a gene $b l a_{\mathrm{SHV}-12}$ while the other isolate has a gene $b l a_{\mathrm{TEM}-52}$ encoding ESBL TEM-52. The presence of the genes encoding ESBL in wild geese in Belgium suggests its possible dissemination in nature and also the possibility of its transfer to humans (Garmyn et al., 2011). During the fall, winter and spring in Oxford peninsula, Maryland-USA, fresh feces was collected from migratory Canada geese (Branta Canadensis). E. coli was most frequently resistant to the following antimicrobials: chlortetracycline, penicillin, ampicillin (AMP), cephalothin and sulfathiazole. There were some seasonal variations in AMR patterns over time in E. coli isolates. It was postulated that if migratory birds are exposed to E. coli from the water, then in winter months this exposition level is lower and subsequently the success of the isolation rate decreases comparing to other parts of the year. The multiple resistance phenotypes was, however, higher during the fall and winter, comparing to spring, possibly due to the lower numbers of samples taken in March (Middleton and Ambrose, 2005). The European wild bird species were tested for shedding of E. coli resistant to the following antimicrobial agents: ampicillin, streptomycin, spectinomycin, chloramphenicol, gentamicin and tetracycline by microdilution method. A total of 226 birds were screened and isolates were further tested for carrying genes that encode the resistance to tetracycline $(\operatorname{tet} \mathrm{A}, \operatorname{tet} \mathrm{B}, \operatorname{tet} \mathrm{C})$, sulfonamides (sull, sul2 and sul3), streptomycin-spectinomycin (aadA, strA, str B) and apramycin-gentamicin (aac(3)-IV) by PCR. The resistance to ampicillin, tetracycline, sulfametoxazole and streptomycin was most frequently found. Among 9 multiple resistant isolates, the tet A, tet $\mathrm{B}, \operatorname{str} \mathrm{A}, \operatorname{sul} 2$ genes were distributed while the aadA2 was found in only two of the E. coli strains. Similar to other reports it was found that wild birds in rural region carry resistant genes almost at the same frequency as birds from the urban area (pigeons raised by man). In birds of prey the resistance was most frequent, therefore the authors postulated that close proximity to farms and the scavenging behavior of these birds contributed to the dissemination of the resistance genes in those birds. Also the contact with the water may be important as a source of resistant microorganisms. This research suggested that most frequently the po- 
ssible resistance transmitters were birds of prey, the waterfowl and passerines (Guenther et al., 2010a). An extended-spectrum of the $\beta$-lactamase producing E. coli was reported from Simōes et al. (2010) during the survey that encompassed wild seagulls residing in beaches of Porto in Portugal. The ESBL phenotype was displayed in $32 \%$ of the samples. All 45 ESBL carriers had the genes encoding ESBL of $b l a_{\text {СТХ. }}$ type, and one isolate possessed the $b l a_{\text {ГЕМ }-52}$ gene. Sequencing reveals that among CTX-M determinants, $18 \%$ were CTX-M-1 type, $9 \%$ were CTX-M-9 type, $39 \%$ was CTX-M-15 type and $34 \%$ was CTXM-32 type. Seagulls appeared to be a possible reservoir, carriers and spreaders of the ESBL producing $E$. coli in the swimming area of Porto. In the Czech Republic a survey was conducted to estimate the presence of the ESBL producing E. coli in cormorants that were shot during the winters 2007-2008. The feces which were collected at the roosting place and the cloacal swabs from the mallards shot during the autumn in 2008 were also included in the research. The ESBL phenotype was detected in $1.6 \%$ of cormorants. The respective genes found were either $b l a_{C T \mathrm{M}-27}$ or $b l a_{C \mathrm{CX} \cdot \mathrm{M}-15}$. The isolates that produce the CTXM-15 also carry the plasmid mediated gene $a a c\left(6^{\prime}\right)-I b-c r$ and class 1 integron with the gene cassettes $d f r A 17$-aadA5. The selection with ciprofloxacin also reveals the PMQR (plasmid mediated quinolone resistance) attributed to the $q 7 r S$ gene and the $a a c\left(6^{\prime}\right)-I b-c r$ in cormorants. The $E$. coli with $a a c\left(6^{\prime}\right)-I b-c r$ gene was also $b l a_{C \mathrm{CX}-\mathrm{M}-15}$ and $b l a_{\mathrm{OXA}-1}$ positive. In the mallards, the ESBL was not found but the qnrS1 gene was detected in 17 birds from the transferable plasmid (Tausova et al., 2012). The research on E. coli that produced the CTX$M$ type ESBL in Germany reveals that from the 172 samples of cloacal swabs or organs, 4 strains of E. coli producing ESBLs were found. The genes bla $a_{\text {ТЕм }}$ and bla $a_{\text {CTX } M}$ were present in the following birds: Eurasian Blackbird, Rock Pigeon, Greater White fronted Goose. Also the tet $A$, tet $B$, strA and $\operatorname{str} B$ genes were displayed, as well as the aadA5 genes and $d f r A 17$ inducing AMR to tetracycline, aminoglycosid antibiotics and to trimethoprim. According to the PFGE data, these strains differ from the isolate of the E. coli found in the urinary tract of a patient in Germany. Besides the fact that E. coli that produces the CTX-M ESBL was present in different birds with different feeding habits, it is possible that the emerging clone of the ESBL producing E. coli exists in Germany (Guenther et al., 2010b). 


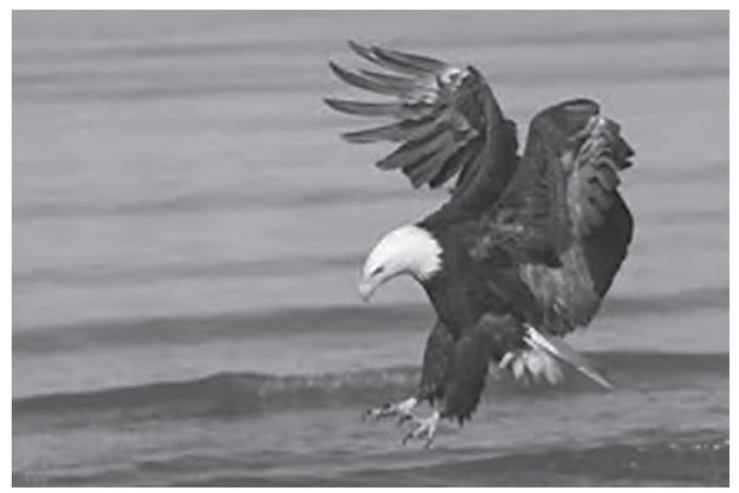

Bird of prey (Bald Eagle, Haliaeetus leucocephalus)

\section{Resistance of $E$. coli in small mammals from wild life}

In southeastern Senegal black rats (Rattus rattus) and chiropterans (Micropteropus pusillus) were trapped and rectal swabs were cultivated to isolate E. coli with the aim of resistance monitoring. In Dar Salam 2, the strains of E. coli from black rats' posses the AMR phenotype. One isolate was resistant to tetracycline (carrying tetA gene) while the other isolate displayed resistance to teteracycline, sulphonamides and to sulphametoxazole-trimethoprim and thus carry tet $\mathrm{A}$ and $s u l 2$ genes. One isolate from the chiropterans was resistant to the TET and carried the tet $A$ gene. From Tambacounda 2, isolates of the $E$. coli from the black rats were resistant to NAL but sensitive to CIP. One E. coli isolate was also found to be resistant to ampicillin, streptomycin, sulphonamides, sulphametoxazole-trimethoprim and tetracycline carrying $b l_{(-\mathrm{XX}-\mathrm{M}-15}$, strA, sul2 and tetA genes. The occurrence of the ESBL phenotype in E.coli from rodents is important because of the possibility of its dissemination from small mammals to humans in the area (Literak et al., 2009). The research on the AMR of the E. coli isolated in small wild mammals residing in proximity to swine farms and the resistances of isolates found in nature was conducted in Ontario Canada. The AMR patterns were more frequent in animals found in the farm environment comparing to natural areas. Isolates from the natural area were resistant to TET and AMP while in wild animals trapped on farm the multiple resistances was found to be attributed to streptomycin, sulfisoxazole and TET ( 2 isolates from one animal), streptomycin, sulfisoxazole, trimethoprim-sulfametoxazole, TET and chloramphenicol (one isolate from the animal trapped on a farm) and in another animals trapped on a farm, the resistance was directed to cefoxitin, TET and chloramphenicol. In wild animals from a natural environment, two isolates (from the same animal) were 
found to carry genes tet $\mathrm{A}$ and $b l a_{\text {TEM }}$. The resistance to TET, sulfonamides and streptomycin in wild animals from the vicinity of the farm is related to the use of antibiotics, although the last two antimicrobials are not so frequently applied. Chloramphenicol resistance was also found in wild mammals from the vicinity of the farm in spite of the fact that this antibiotic had been withdrawn over 20 years ago. However, the genes conferring the resistant phenotype did manage to be preserved in the environment, as postulated in their study. The integron associated genes aadA and sul1 were not present in wild animals from the nature, but were common finding in animals trapped around the farm. The tet $\mathrm{B}$ gene was most frequent in wild animals from the vicinity of a farm and yet was absent in wild animals from the nature (Kozak et al., 2009). The resistance of the E. coli isolated in small mammals that were trapped around swine farms, natural habitats, in vicinity of landfills and residential areas in Ontario, Canada was also investigated (Allen et al., 2011). Animals that were trapped included: Peromyscus sp (deer mouse), M. musculus (house mouse), B. brevicauda (Northern short tailed Shrew), M. pennsylvanicus (Meadow vole/ mouse), T. striatus (Eastern chipmunk) and Rattus norvegicus (Berkenhout). In animals from swine farms, the most common resistance was to tetracycline. In residential areas resistance to ampicillin was prevalent while in the vicinity of landfills, the resistance in E. coli was attributed to ampicillin, kanamycin and chloramphenicol. Interestingly, the resistance of $E$. coli from animals trapped in natural environment was attributed exclusively to chloramphenicol (one isolate). The finding of the resistance to ampicillin, streptomycin, sulfaxazole and tetracycline was much higher in the vicinity of swine farms comparing to the finding in residential area. The risk of multiple resistance of $E$. coli from animals trapped close to landfills and in residential areas was not significant thus implicating that contamination is not present in the area. Most of the AMR genes were distributed in wild animals residing close to the swine farms and they included: $b l a_{\mathrm{TEM}}, b l a_{\mathrm{CMY}}$, strA-strB, aadA, aphA1, sull, sul2, sul3, tetA, tet $\mathrm{B}$, tet $\mathrm{C}$ and $\mathrm{cm} l \mathrm{~A}$. During the hunting season wild rabbits in North Portugal were tested for resistance patterns of E. coli and Enterococcus sp. Resistance to 3 or more antimicrobials were detected in 4 fecal samples. Overall the AMR rate was low since 6 feces from the 44 samples showed a reduced susceptibility to antimicrobials. This was partially explained by the fact that rabbits do not come in close contact to animal waste, since they are herbivores. In very few samples genes corresponding to certain resistance mechanisms were detected. In ampicillin resistant $E$. coli the $b l a_{\text {TEM }}$ gene was found, gentamicin resistant isolates carry aac(3)-II gene, streptomycin resistance was aadA positive, sulfamethoxazole and trimethoprim was related to sull and sul2 genes and sul3 gene while teteracycline resistance was marked by the presence of tet $\mathrm{A}$ and 
tet $\mathrm{B}$ genes indicating active efflux. Cholramphenicol resistance was directed over $\mathrm{cmlA}$ gene ( Silva et al., 2010). In the Shimokita Penninsula in Japan there is a high density of Japanese macaques (the Snow monkey) that sometimes damages the crops and often invades homes of the citizens. The fecal samples were subsequently collected in order to do research on AMR of the E. coli and consider possibility of resistance transfer to humans. The $E$. coli was isolated from 159 out of 265 samples of wild macaques and from 17 out of 20 captured macaques during December 2005 and from October to December 2006. Fiftyeight isolates were resistant to the following antimicrobials: 17 to cephalothin, 13 to ampicillin, 27 to cephalothin and ampicillin and one isolate was resistant to streptomycin. Pathogenic E. coli was not found applying agglutination test. It was suggested that contact with humans did not influence the resistance phenotype in the Peninsula (Ogawa et al., 2011).

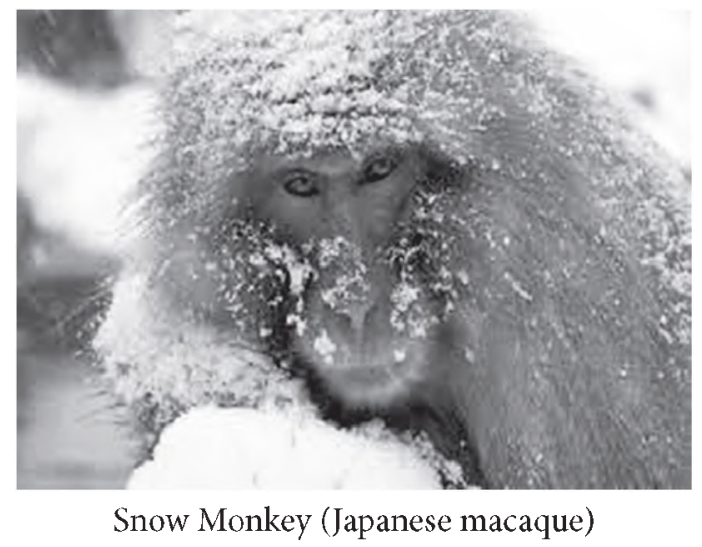

\section{CONCLUSION}

In conclusion the most probable reservoirs of resistant bacteria in wildlife are water birds and birds of prey. This coincides with the fact that those birds happen to come close to the human sewage and waste waters and may become infected with the resistant bacteria. Reports on antimicrobial resistance in wildlife are higher in the parts of Europe where human density is significant, but this is not a rule. Sometimes the resistance levels in E. coli are more attributed to the type of wild animal species than to their habitat. Namely, wild birds tend to come in contact with waste more often than other wild animals. They also often live in urban area and more frequently carry $E$. coli (Guenther et al., 2011). Since animals from wildlife are found to be carriers of E.coli harboring different AMR patterns the environment must be protected from the pollution, thus preserving the wild life on our planet. 


\section{REFERENCES}

1. Allen S.E., Boerlin P., Janecko N., Lamsden J.S., Barker I.K., Pearl D.L., Reid-Smith R.J., Jardine C.: Antimicrobial resistance in generic Escherichia coli isolates from wild small mammals living in swine farm, residential, landfill and natural environments in Southern Ontario, Canada. Applied and Environmental Microbiology, 77, 882-888, 2011.

2. Cole D., Drum D.J.V., Stallknecht D.E., White D.G., Lee M.D., Ayers S., Sobsey M., Maurer J.J.: Free-living Canada geese and antimicrobial resistance. Emerging Infectious Diseases 11, 935-938, 2005.

3. Costa D., Poeta P., Sáenz Y., Vinué L., Rojo-Bezares B., Jouini A., Zarazaga M., Rodrigues J., Torres C.: Detection of Escherichia coli harboring extended-spectrum $\beta$-lactamases of the CTX-M, TEM and SHV classes in faecal samples of wild animals in Portugal. Journal of Antimicrobial Chemotherapy, 58, 1311-1312, 2006.

4. Costa D., Poeta P., Sáenz Y., Vinué L., Coelho A.C., Matos M., Rojo-Bezares B., Rodrigues J., Torres C.: Mechanisms of antibiotic resistance in Escherichia coli isolates recovered from wild animals. Microbial Drug Resistance, 14, 71-77, 2008.

5. Garmyn A., Haesebrouck F., Hellebuyck T., Smet A., Pasamans F., Butaye P., Martel A.: Presence of extended-spectrum $\beta$-lactamase-producing Escherichia coli in wild geese. Journal of Antimicrobial Chemotherapy, 66, 1643-1644, 2011.

6. Guenther S., Grobbel M., Lübke-Becker A., Goedecke A., Friedrich ND., Wieler L.H., Ewers C.: Antimicrobial resistance profiles of Escherichia coli from common European wild bird species. Veterinary Microbiology, 144, 219-225, 2010a.

7. Guenther S., Grobbel M., Beutlich J., Bethe A., Friedrich N.D., Goedecke A., Lübke-Becker A., Guerra B., Wieler L.H., Ewers C.: CTX-M-15-type extended-spectrum beta-lactamases-producing Escherichia coli from wild birds in Germany. Environmental Microbiology Reports, 2, 641-645, $2010 \mathrm{~b}$.

8. Guenther S., Ewers C., Wieler L.H.: Extended-spectrum beta-lactamases producing $E$. coli in wildlife, yet another form of the environmental pollution? Frontiers in Microbiology, 2, 246, 1-13, 2011.

9. Kozak G.K., Boerlin P., Janecko N., Reid-Smith R.J., Jardine C.: Antimicrobial resistance in Escherichia coli isolates from swine and wild small mammals in the proximity of swine farms and in natural environments in Ontario, Canada. Applied and Environmental Microbiology, 75 , 559-566, 2009.

10. Literak I., Dolejska M., Cizek A., Djigo C.A.T., Konecny A., Koubek P.: Reservoirs of antibiotic-resistant Enterobacteriaceae among animals 
sympatric to humans in Senegal: extended-spectrum beta-lactamases in bacteria in black rat (Rattus rattus). African Journal of Microbiology Research, 3, 751-754, 2009.

11. Middleton J.H., Ambrose A.: Enumeration and antibiotic resistance patterns of fecal indicator organisms isolated from migratory Canada geese (Branta Canadensis). Journal of Wildlife Diseases, 41, 334-341, 2005.

12. Ogawa K., Yamaguchi K., Suzuki M., Tsubota T., Ohya K., Fukushi H.: Genetic characteristics and antimicrobial resistance of Escherichia coli from Japanese Macaques (Macaca Fuscata) in rural Japan. Journal of wildlife diseases 47, 261-270, 2011.

13. Silva N., Igrejas G., Figueiredo N., Goncalves A., Radhouani H., Rodrigues J., Poeta P.: Molecular characterization of antimicrobial resistance in enterococci and Escherichia coli isolates from European wild rabbit (Oryctolagus cuniculus). Science of the Total Environment, 408, 4871-4876, 2010.

14. Simões R.R., Poirel L., Da Costa P.M., Nordmann P.: Seagulls and beaches as reservoirs for multidrug-resistant Escherichia coli. Emerging Infectious Diseases, 16, 110-112, 2010.

15. Suvajdžić Lj., Lević J., Velhner M., Pavkov S., Potkonjak A., Milanov D., Cabarkapa I.: Common food borne bacterial diseases of poultry. In: Proceedings of the XV International Feed Technology Symposium, 03-05 Oktobar, Novi Sad, Editor Jovanka Lević, 2012, p. 154-165.

16. Tausova D., Dolejska M., Cizek A., Hanusova L., Hrusakova J., Svoboda O., Camlik G., Literak I.: Escherichia coli with extended-spectrum $\beta$-lactamase and plasmid-mediated quinolone resistance genes in great cormorants and mallards in Central Europe. Journal of Antimicrobial Chemotherapy, 67, 1103-1107, 2012.

Primljeno: 15.10.2012.

Odobreno: 01.11.2012. 